\title{
Osmoresistance of spores from Bacillus subtilis and the effect of ssp mutations
}

\author{
Sandra M. Ruzal, Alejandro F. Alice and Carmen Sanchez-Rivas
}

Author for correspondence: Carmen Sanchez-Rivas. Fax: +5417761074.

e-mail: sanchez@genbac.edu.ar

Facultad de Ciencias Exactas y Naturales, Departamento de Química Biológica, Ciudad Universitaria, Pabellón II, Piso 4, 1428 Buenos Aires, Argentina

\begin{abstract}
Spores of Bacillus subtilis show similar plating efficiency on media with or without $1.5 \mathrm{M} \mathrm{NaCl}$. In contrast, vegetative cells are osmosensitive unless the stationary phase has been reached. In the present work, loss of heat and osmotic resistance during germination was studied. Their kinetics and sensitivity to protein synthesis inhibition were different: heat resistance was lost first and even in the presence of chloramphenicol, whereas loss of osmotolerance occurred later and was inhibited in the presence of this antibiotic. The influence of spore-associated small acid-soluble proteins (SASPs) on spore osmotolerance was investigated using ssp mutants: all produced spores which germinated poorly and were sensitive to osmotic strength. SASP-E deficiency was particularly significant. Spore osmotolerance was largely restored in complementation assays performed with cloned ssp genes. It is possible that germination-associated degradation of SASP proteins provides osmotically significant levels of amino acids (especially glutamate).
\end{abstract}

Keywords: Bacillus subtilis, spore osmoresistance, small acid-soluble protein, ssp

\section{INTRODUCTION}

Bacteria subjected to an osmotic upshock either develop specific transport systems for appropriate osmolytes $\left(\mathrm{K}^{+}\right.$, proline, etc.) or synthesize osmoprotectants such as glutamate, glycine betaine or trehalose (Csonka \& Hanson, 1991). In Bacillus subtilis, as in Staphylococcus aureus (Townsend \& Wilkinson, 1992; Whatmore et al., 1990; Whatmore \& Reed, 1990), proline and $\mathrm{K}^{+}$seem to be the principal solutes accumulated, and it is noteworthy that few Pro ${ }^{-}$mutants have been isolated. In addition, $B$. subtilis cultures respond to osmotic upshock only during the early stationary phase or initiation of sporulation, which share sensors and regulators (Ruzal \& SanchezRivas, 1994).

In contrast to vegetative cultures, B. subtilis spores form colonies equally well on media with or without added $1.5 \mathrm{M} \mathrm{NaCl}$. The abundant spore-associated small acidsoluble proteins (SASPs) are rich in glutamate, a known osmoprotectant (Measures, 1975; Johnson \& Tipper, 1981); the involvement of SASPs in osmotolerance during germination was therefore suspected. In the present study, mutants of the different ssp genes were examined. Germination studies were performed and loss of heat and osmotic resistance was monitored. Complementation experiments with the cloned ssp genes are also reported.

Abbreviation: SASP, small acid-soluble protein

\section{METHODS}

Bacterial strains. B. subtilis strains and plasmids used are listed in Table 1.

Media and assays. Growth was carried out in Luria-Bertani (LB) medium or Schaeffer sporulation (D) medium (Schaeffer $e t$ al., 1965). Solid media contained $1.5 \%$ agar. DN medium was D medium containing $1.5 \mathrm{M} \mathrm{NaCl}$ as osmotic supplier. For comparison, in some experiments sucrose $(0.6 \mathrm{M})$ or succinate $(0.75 \mathrm{M})$ were used as alternative osmotic suppliers. Antibiotics used were $\left(\mu \mathrm{g} \mathrm{ml}^{-1}\right)$ : chloramphenicol, 3 ; kanamycin, 10 [or 50 in media containing $1.5 \mathrm{M} \mathrm{NaCl}$, to compensate for inactivation due to the hypertonicity (Chang \& Cohen, 1979)].

Spores from 2-d-old cultures (D medium, $37^{\circ} \mathrm{C}$ ) were collected in $10 \mathrm{ml}$ sterile distilled water, washed twice and heated for $20 \mathrm{~min}$ at $70^{\circ} \mathrm{C}$ to eliminate non-sporulated cells. The pellet was kept at $-20^{\circ} \mathrm{C}$.

Percentage osmoresistance was calculated from the number of colonies on DN medium compared to that on D medium, using either cultures grown in D medium from vegetative $(t-2)$ to early stationary phase $(t 0-t+2)$, or spore suspensions. $t-2$ and t0 indicate the time in hours relative to the early stationary phase or initiation of sporulation which were taken as time zero $(20)$.

For germination, heat-activated spores $\left(10 \min\right.$ at $\left.70^{\circ} \mathrm{C}\right)$ were diluted in twofold-concentrated D medium (D2 $\times$ ) containing $4 \mathrm{mM}$ alanine and $0.5 \%$ glucose as germinants and incubated at $37^{\circ} \mathrm{C}$ in a shaker. At intervals, counts were done on D and DN media, and on DN medium after 10 min heat at $70^{\circ} \mathrm{C}$ to determine the number of remaining heat-resistant spores. 
Table 1. B. subtilis strains and plasmids

\begin{tabular}{|c|c|c|}
\hline $\begin{array}{l}\text { Strain or } \\
\text { plasmid }\end{array}$ & Relevant genotype & $\begin{array}{l}\text { Origin or } \\
\text { reference* }\end{array}$ \\
\hline \multicolumn{3}{|c|}{ B. subtilis } \\
\hline YB886 & $m e t B 5 \operatorname{trp} C 2 \times$ in $S P \beta^{s}$ & $\begin{array}{l}\text { Yasbin et al. } \\
(1980)\end{array}$ \\
\hline CU1050 & $\begin{array}{l}S P \beta^{s} \text { sup-3 metB5 thr-5 leuA } A 8 \\
\text { pur } A 16 \text { sspC }\end{array}$ & Zahler (1982) \\
\hline 168 & $\operatorname{trp} C 2$ & BGSC \\
\hline PS355 & $\operatorname{trp} C 2 \operatorname{ssp} A \operatorname{ssp} B \mathrm{Cm}^{\mathrm{r}}$ & P. Setlow \\
\hline PS482 & $\operatorname{trp} C 2 \operatorname{ssp} A \operatorname{ssp} B \operatorname{ssp} E \mathrm{Cm}^{\mathrm{r}}$ & P. Setlow \\
\hline PS483 & $\operatorname{trp} C 2 \operatorname{ssp} E \mathrm{Cm}^{\mathrm{r}}$ & P. Setlow \\
\hline YB886E† & sspE in YB886 background & This paper \\
\hline \multicolumn{3}{|l|}{ Plasmids } \\
\hline pUB110 & $\mathrm{Km}^{\mathrm{r}}$ & BGSC \\
\hline pPS535 & pUB110 $+s s p B$ coding sequence & P. Setlow \\
\hline pPS549 & pUB110 $+\operatorname{ssp} A$ coding sequence & P. Setlow \\
\hline pPS623 & pUB110 + sspE coding sequence & P. Setlow \\
\hline
\end{tabular}

* BGSC, Bacillus Genetic Stock Center, Ohio State University, Columbus, Ohio, USA; P. Setlow, University of Connecticut Health Center, Farmington, Connecticut, USA.

†Obtained after transformation of YB886 competent cells with DNA from PS483 and selecting $\mathrm{Cm}^{\mathrm{r}}$ colonies.

Chloramphenicol $\left(200 \mu \mathrm{g} \mathrm{ml}^{-1}\right)$ was added when protein synthesis inhibition was required.

Plasmid DNA was prepared according to Birnboim \& Doly (1979), and was introduced into protoplasts according to Chang \& Cohen (1979) and as modified in our laboratory (Rubinstein et al., 1988).

DNA was obtained essentially as described by Saito \& Miura (1963). Bacterial transformation was performed with competent cells as described by Anagnastopoulos \& Spizizen (1961) and modified by Niaudet \& Erlich (1979).

\section{RESULTS}

Spore suspensions plated on media with or without $1.5 \mathrm{M}$ $\mathrm{NaCl}$ showed similar viable counts. In contrast, viable counts of vegetative cultures on DN plates were less than $1 \%$ unless stationary phase had been reached. The use of other osmotic suppliers (sucrose and succinate) gave the same results as previously shown for the stationary-phasedependent response (Ruzal \& Sanchez-Rivas, 1994). Thus, in addition to the known resistance to solvents, UV light, heat and lysozyme, spores are resistant to osmotic stress. Two questions were therefore addressed:

- at what time is osmoresistance lost during germination?

- what is produced (or which genes are turned on/off) by germinating spores on high- $\mathrm{NaCl}$-containing media, which allow the bacteria to form colonies?

\section{Germination experiments and loss of spore resistance}

Changes in osmo- and heat resistance during germination are shown in Fig. 1 (a). Loss of heat resistance occurred at
30 min whether or not chloramphenicol was added to inhibit protein synthesis, which normally started later in this medium (Moir \& Smith, 1990; Sanchez-Salas et al., 1992). Osmoresistance was retained for longer: after $60 \mathrm{~min}$ incubation, germinating spores were still osmoresistant. The presence of chloramphenicol inhibited loss of osmotolerance. The chronology of events taking place during germination and leading to the loss of resistance is not known precisely but the spore envelopes, the first barrier to several stress factors, are degraded first. Heat resistance is generally attributed to calcium diaminopimelate in the cortex, which is one of the later components to be synthesized (Errington, 1993). During germination, hydration and loss of heat resistance and diaminopimelate take place early, without any detectable metabolic activity. In contrast, loss of osmoresistance occurs later and requires protein synthesis.

The SASPs present in spores were suspected as being the agents of osmoresistance. They represent $20 \%$ of total protein content and, being degraded at germination, they provide the amino acids necessary to initiate protein synthesis (Sussman \& Setlow, 1991; Sanchez-Salas et al., 1992). SASPs are also rich (15-29\% of residues) in glutamate, a possible osmoprotectant (Measures, 1975). These facts led us to investigate their involvement using a genetic approach.

\section{ssp mutations and spore osmoresistance}

The SASPs constitute two immunologically distinct and differently regulated categories of proteins: the $\alpha / \beta$ type and the $\gamma$ type. While only one gene, ssp E, accounts for the
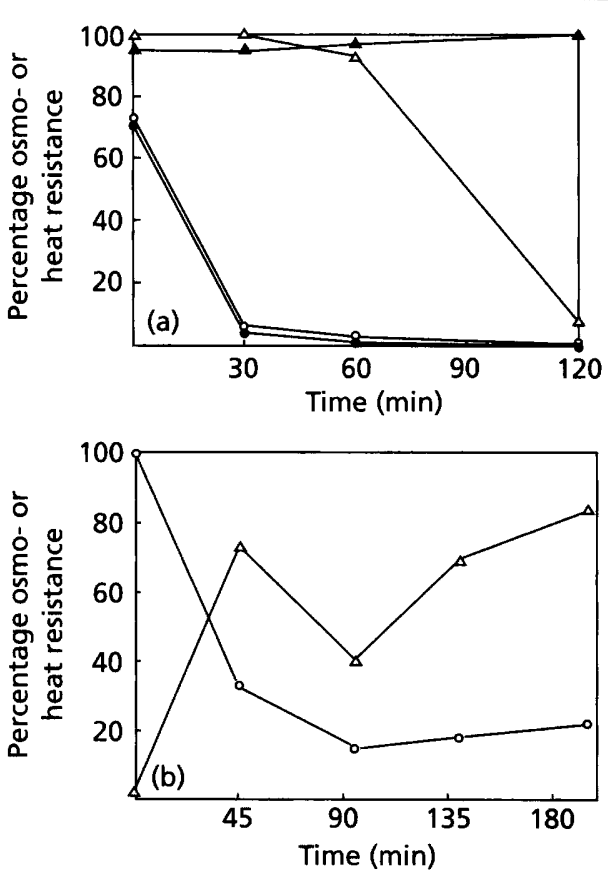

Fig. 1. Osmotic and heat resistance during germination of (a) strain YB886 (wild-type) and (b) strain PS483 (sspE) B. subtilis spores. Osmotic $(\triangle)$ and heat $(O)$ resistance were determined as described in Methods. $\boldsymbol{A}, \boldsymbol{O}$, Experiments done in the presence of $200 \mu \mathrm{g}$ chloramphenicol ml $\mathrm{m}^{-1}$. 


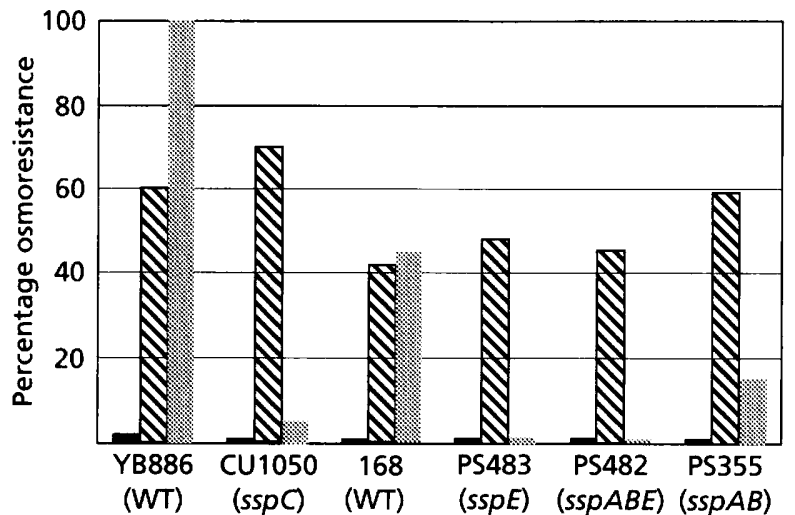

B. subtilis strain

Fig. 2. Osmoresistance of vegetative cultures and spores of $B$.

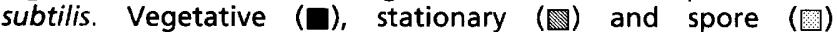
osmoresistance was determined as described in Methods. WT, wild-type.

Table 2. Complementation experiments

\begin{tabular}{|c|c|c|}
\hline $\begin{array}{l}\text { Strain (relevant } \\
\text { phenotype) }\end{array}$ & Plasmid & $\begin{array}{l}\% \text { Osmo- } \\
\text { resistance* }\end{array}$ \\
\hline \multirow[t]{5}{*}{168 (wild-type) } & None & $34 \cdot 0$ \\
\hline & pUB110 & $9 \cdot 0$ \\
\hline & pPS549 $(+\operatorname{ssp} A)$ & $0 \cdot 1$ \\
\hline & pPS535 $(+s s p B)$ & $4 \cdot 5$ \\
\hline & pPS623 (+sspE) & $13 \cdot 6$ \\
\hline \multirow[t]{5}{*}{ PS482 (sspABE) } & None & 0.6 \\
\hline & pUB110 & $0 \cdot 6$ \\
\hline & pPS549 $(+s s p A)$ & $13 \cdot 8$ \\
\hline & pPS535 $(+s s p B)$ & 6.9 \\
\hline & pPS623 $(+s s p E)$ & $16 \cdot 3$ \\
\hline \multirow[t]{5}{*}{ PS483 (sspE) } & None & $1 \cdot 5$ \\
\hline & pUB110 & $4 \cdot 0$ \\
\hline & $\operatorname{pPS} 549(+s s p . A)$ & $0 \cdot 8$ \\
\hline & pPS535 $(+s s p B)$ & 0.6 \\
\hline & pPS623 (+sspE) & $18 \cdot 8$ \\
\hline \multirow[t]{4}{*}{ CL1050 (sspC) } & pUB110 & $6 \cdot 7$ \\
\hline & pPS549 $(+\operatorname{ssp} A)$ & $3 \cdot 0$ \\
\hline & pPS535 $(+s s p B)$ & $6 \cdot 3$ \\
\hline & pPS623 $(+s s p E)$ & $13 \cdot 0$ \\
\hline
\end{tabular}

* Spores of each plasmid-bearing strain were prepared and their osmoresistance determined as described in Methods.

$\gamma$ type, several genes $(\operatorname{ss} p A, B, C$ and $D)$ account for the $\alpha / \beta$ type and mutations in any one of them are compensated for by the activity of others. (Mason \& Setlow, 1986; Hackett \& Setlow, 1987; Mason et al., 1988; Setlow, 1988). Spores of ssp mutants germinate poorly and, in addition, are very sensitive to osmotic strength (Fig. 2), sspE mutants being significantly the most sensitive. In the YB886 genetic background (YB886E), spore osmoresistance shifted from $90 \%$ to $0.5 \%$ in the

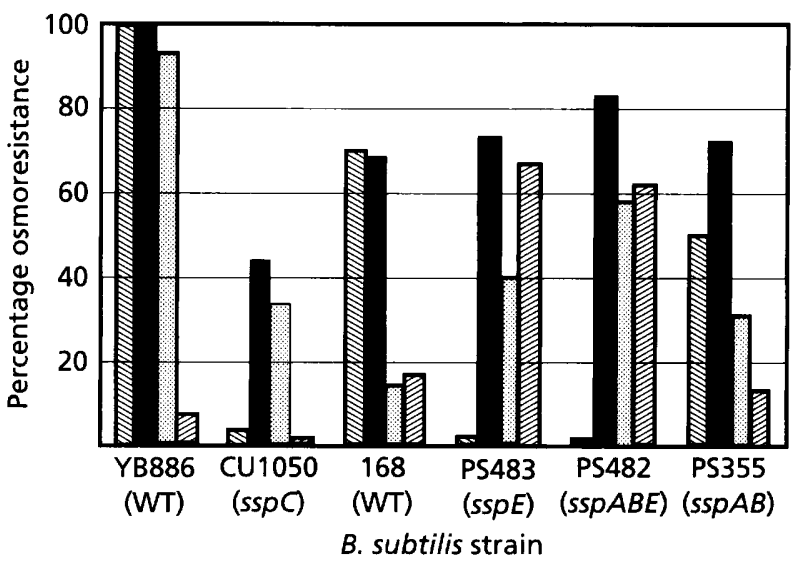

Fig. 3. Development of osmotic resistance of wild-type and ssp mutants during germination. Germination was carried out as described in Methods. Osmoresistance was determined after 0 (四), 30 (ם), 60 (圆) and 120 (缃) min for strains YB886 and CU1050; and after 0 (田), $45(\square), 125$ (圆) and 180 (四) min for strains 168, PS483, PS482 and PS355.

presence of the $s s p E$ mutation. On the other hand, strain PS355 [lacking two of the five $s s p(\alpha / \beta)$ genes], produces spores more osmoresistant than those of strain PS483, lacking only sspE (Fig. 2). The contribution of minor SASPs and the coordinate regulation of all the $\alpha / \beta$ genes (Mason et al., 1988; Setlow, 1988) should restore a normal SASP $\alpha / \beta$ content in strain PS355. In order to ensure that this deficiency is indeed a spore property, osmoresistance during vegetative and stationary growth phases was tested (Fig. 2). In all these ssp mutants, osmoresistance can be induced at levels comparable to their wild-type parental counterparts.

Since the relevant $s s p$ genes have been cloned (Hackett \& Setlow, 1987; Connors et al., 1986), complementation of the defective spore osmoresistance trait was investigated. Recombinant plasmids were introduced into the mutant strains and spores were collected from selective plates containing $10 \mu \mathrm{g}$ kanamycin $\mathrm{ml}^{-1}$ to ensure plasmid maintenance. As shown in Table 2, spores from strain PS483 (sspE) were complemented only when the $s s p E$ gene was added in trans. However, with mutant strain PS482 (ssp $A B E$ ), plasmids containing $s s p A, B$ or $E$ complemented the osmotic defect. Surprisingly, the presence of plasmid pUB110 (without insert) in the Ssp ${ }^{+}$ strain 168 resulted in less osmotolerant spores. This behaviour is discussed later.

\section{Germination of ssp mutant strains}

Spores from SASP-defective strains germinated poorly, as revealed by the failure of a significant fraction of spores to lose heat resistance during the first $2 \mathrm{~h}$ of germination (Fig. 1b). In addition, osmoresistance increased 10-20fold after 30-60 min of germination (Fig. 1b, Fig. 3) before falling to vegetative levels after $180 \mathrm{~min}$. This behaviour cannot be attributed only to low germination since strain CU1050 ( $s p C$ ), which, in contrast to the other $s s p$ mutants, germinates normally with respect to loss of 
heat resistance, showed the same pattern in loss of osmoresistance. In the AGFK medium of Wax \& Freese (1968), germination of these strains is faster (according to data on loss of heat resistance), but again osmoresistance increased during the early period of germination before falling to vegetative levels (data not shown). Since SASPs were expected to be degraded during this period, this increase in osmoresistance may have been due to the amino acids released by their proteolysis. In the presence of chloramphenicol, protein synthesis and outgrowth are inhibited, but SASP proteolysis may proceed since the specific protease involved is already present in the forespore. This may explain the prolonged phase of osmoresistance seen in Fig. 1(a) in the presence of chloramphenicol.

\section{DISCUSSION}

In this paper we present strong evidence that the SASP content of $B$. subtilis spores enables them to germinate on hypertonic media. The $\alpha / \beta$ SASP proteins, being linked to spore DNA, are thought to be involved in DNA. supercoiling and in the resistance of spores to UV radiation (Francesconi et al., 1988; Mason \& Setlow, 1986; Nicholson \& Setlow, 1990; Setlow et al., 1992) and to hydrogen peroxide (Setlow \& Setlow, 1993). The $\gamma$. type protein (SASP-E) is free in the spore cytoplasm and no clear role has been reported for it other than providing: amino acids inside the germinating cell (Francesconi $e t a l$., 1988). However, both SASP species appear to be important for germination in hyperosmotic media, with SASP-E being particularly significant. In fact, of all the SASPs, SASP-E would be best suited to a role in osmoresistance since its glutamate content is highest, it is most abundant and, being free in the cytoplasm, it would be immediately accessible to degradation. The $\alpha / \beta$-type proteins are mostly associated with the nucleoid and would be degraded when removed from DNA. A fraction, however, is still available in the cytoplasm (Francesconi $e t$ al., 1988) and this fraction can be sequestered in strains containing plasmids (Nicholson \& Setlow, 1990). The contribution of $\alpha / \beta$ SASPs to osmoresistance would then be diminished. This was in fact observed: the presence of plasmid pUB110 (a multicopy replicon) in the wild-type strain resulted in a clear reduction of spore osmotolerance. This reduction was not so severe if the cloned $s s p E$ gene was also present (Table 2). The negative titration effect due to the presence of plasmid DNA may explain the failure to recover completely a wild phenotype in the complementation experiments reported here (Table 2). In SASP-E defective mutant strains, the increase in osmoresistance after the first period of germination (Fig. 3) would correlate with the degradation of $\alpha / \beta$ SASPs.

The pool of SASPs present in spores is important to overcome stresses such as UV radiation, hydrogen peroxide and, as shown here, osmotic strength. Whether their contribution to this resistance is only as osmolyte suppliers (amino acids and glutamate in particular), or whether they are also the transcription factors of genes involved in the osmotic response, remains an open question. Their capacity to induce negative DNA- superhelicity should have a regulatory effect on certain promoters; in fact, in Escherichia coli, supercoiling and topoisomerase activity have been postulated to influence the osmotic stress response (Graeme-Cook et al., 1989; Ni Bhriain et al., 1989). It is worth noting that only during two periods, germination of spores and entry into the stationary phase, can the osmotic response be induced. In addition, during both periods the chromosome is condensed (Le Hegarat et al., 1978; Nicholson \& Setlow, 1990), and this would allow expression of the specific gene functions required for the osmotic response. The relationship between the two response periods will be the subject of future investigations.

\section{ACKNOWLEDGEMENTS}

This research was supported by grants from the Consejo Nacional de Investigaciones Científicas y Técnicas (CONICET) and the University of Buenos Aires (UBA). The authors are grateful to $P$. Setlow for the provision of valuable strains and plasmids and for stimulating correspondence during the development of this work. The training of S. M. Ruzal was supported by a fellowship awarded by the CONICET.

\section{REFERENCES}

Anagnastopoulos, C. \& Spizizen, J. (1961). Requirements for transformation in Bacillus subtilis. J Bacteriol 81, 741-746.

Birnboim, H. \& Doly, J. (1979). A rapid alkaline extraction procedure for screening recombinant plasmid DNA. Nucleic Acids Res 7, 897-903.

Chang, S. \& Cohen, S. N. (1979). High frequency transformation of Bacillus subtilis protoplasts by plasmid DNA. Mol \& Gen Genet 168 , 111-115.

Connors, M. J., Mason, J. M. \& Setlow, P. (1986). Cloning and nucleotide sequence of genes for three small, acid-soluble spore proteins of Bacillus subtilis spores. J Bacteriol 166, 417-425.

Csonka, L. N. \& Hanson, A. D. (1991). Procaryotic osmoregulation: genetics and physiology. Annu Rev Microbiol 45, 569-606.

Errington, J. (1993). Bacillus subtilis sporulation: regulation of gene expression and control of morphogenesis. Microbiol Rev 57, 1-13.

Francesconi, S. C., MacAlister, T. J., Setlow, B. \& Setlow, P. (1988). Immunoelectron microscopic localization of small, acid-soluble spore proteins in sporulating cells of Bacillus subtilis. J Bacteriol 170, 5963-5967.

Graeme-Cook, K. A., May, G., Bremer, E. \& Higgins, C. F. (1989). Osmotic regulation of porin expression: a role for DNA supercoiling. Mol Microbiol 3, 1287-1294.

Hackett, R. H. \& Setlow, P. (1987). Cloning, nucleotide sequencing and genetic mapping of the gene for small, acid-soluble spore protein gamma of Bacillus subtilis. J Bacteriol 169, 1985-1992.

Johnson, W. C. \& Tipper, D. J. (1981). Acid-soluble spore proteins of Bacillus subtilis. J Bacteriol 146, 972-982.

Le Hegarat, F., Guillen, N., Fleury, A. M. \& Hirschbein, L. (1978). Comparative studies on purified nucleoids of Bacillus subtilis during growth and sporulation. In Spores VII, pp. 193-200. Edited by G. Chambliss and J. C. Vary. Washington, DC: American Society for Microbiology.

Mason, J. M. \& Setlow, P. (1986). Essential role of small, acidsoluble spore proteins in resistance of Bacillus subtilis spores to UV light. J Bacteriol 167, 174-178.

Mason, J. M., Hackett, R. H. \& Setlow, P. (1988). Studies on the 
regulation of expression of genes coding for small acid-soluble proteins of Bacillus subtilis spores using lac $Z$ gene fusions. J Bacteriol 170, 239-244.

Measures, J. C. (1975). Role of amino acids in osmoregulation of non-halophilic bacteria. Nature 257, 398-400.

Moir, A. \& Smith, D. (1990). The genetics of bacterial spore germination. Annu Rev Microbiol 44, 531-533.

Ni Bhriain, N., Dorman, C. J. \& Higgins, C. F. (1989). An overlap between osmotic and anaerobic stress responses: a potential role for DNA supercoiling in the coordinate regulation of gene expression. Mol Microbiol 3, 933-942.

Niaudet, B. \& Erlich, S. (1979). In vitro genetic labeling of Bacillus subtilis cryptic plasmid pHV400. Plasmid 2, 48-58.

Nicholson, W. L. \& Setlow, P. (1990). Dramatic increase in negative superhelicity of plasmid DNA in the forespore compartment of sporulating cells of Bacillus subtilis. J Bacteriol 172, 7-14.

Rubinstein, C. P., Moratinos, L. C., Coso, O. A. \& Sanchez-Rivas, C. (1988). Improvements in the transformation of Bacillus subtilis protoplasts with plasmid DNA. FEMS Microbiol Lett 56, 67-70.

Ruzal, S. M. \& Sanchez-Rivas, C. (1994). Physiological and genetic characterization of the osmotic stress response in Bacillus subtilis. Can J Microbiol 40, 140-144.

Saito, H. \& Miura, K. (1963). Preparation of transforming deoxyribonucleic acid by phenol treatment. Biocbim Biopbys Acta $\mathbf{7 2}$ 16191630

Sanchez-Salas, J. L., Santiago-Lara, M. L., Setlow, B., Sussman, M. D. \& Setlow, P. (1992). Properties of Bacillus megaterium and Bacillus subtilis mutants which lack the protease that degrades small acid-soluble proteins during spore germination. $J$ Bacteriol 174, 807-814.

Schaeffer, P., Millet, J. \& Aubert, J. (1965). Catabolic repression of bacterial sporulation. Proc Natl Acad Sci US A 554, 701-711.

Setlow, P. (1988). Small, acid-soluble spore proteins of Bacillus species: structure, synthesis, genetics, function and degradation. Annu Rev Microbiol 42, 319-338.

Setlow, B. \& Setlow, P. (1993). Binding of small, acid-soluble spore proteins to DNA plays a significant role in the resistance of Bacillus subtilis spores to hydrogen peroxide. Appl Environ Microbiol 59, 3418-3423.

Setlow, B., Sun, D. \& Setlow, P. (1992). Interaction between DNA and $\alpha / \beta$-type small, acid-soluble spore proteins: a new class of DNA-binding protein. J Bacteriol 174, 2312-2322.

Sussman, M. D. \& Setlow, P. (1991). Cloning, nucleotide sequence and regulation of the Bacillus subtilis gpr gene which codes for the protease that initiates degradation of small, acid-soluble proteins during spore germination. J Bacteriol 173, 293-300.

Townsend, D. E. \& Wilkinson, B. J. (1992). Proline transport in Staphylococcus aureus: a high-affinity system and a low affinity system involved in osmoregulation. $J$ Bacteriol 174, 2702-2710.

Wax, R. \& Freese, E. (1968). Initiation of the germination of Bacillus subtilis spores by a combination of compounds in place of $\mathrm{L}$-alanine. J Bacteriol 95, 433-438.

Whatmore, A. M. \& Reed, R. H. (1990). Determination of turgor pressure in Bacillus subtilis: a possible role for $\mathrm{K}^{+}$in turgor regulation. J Gen Microbiol 136, 2521-2526.

Whatmore, A. M., Chudek, J. A. \& Reed, R. H. (1990). The effects of osmotic upshock on the intracellular solute pools of Bacillus subtilis. J Gen Microbiol 136, 2527-2535.

Yasbin, R., Fields, P. \& Anderson, B. (1980). Properties of Bacillus subtilis 168 freed of their natural prophages. Gene 12, 155-159.

Zahler, S. A. (1982). Specialized transduction in Bacillus subtilis. In The Molecular Biology of the Bacilli, pp. 269-305. Edited by D. A. Dubnau. New York: Academic Press.

Received 11 January 1994; revised 30 March 1994; accepted 8 April 1994. 